\title{
Forage Kochia Helps Fight Range Fires
}

\section{Forage kochia greenstrips have a successful reputation in retarding Western rangeland wildfires.}

\author{
By R. Deane Harrison, Blair L. Waldron, Kevin B. Jensen, Richard Page, Thomas A. Monaco, W. \\ Howard Horton, and Antonio J. Palazzo
}

$\mathrm{R}$ angeland wildfires in the Intermountain West have dramatically increased since 1979 , placing a major economic burden on private and public land managers to control or suppress these fires (Pellant 1990).

Perhaps more important is the loss of natural resources and degradation of ecological sites and ecosystems that result from repeated burning. Frequent wildfires prevent the establishment of native shrub, forb, and perennial grass plant communities and increase the dominance of invasive annual weedy species.

One of the major contributors to increased wildfires is cheatgrass (Bromus tectorum), which inhibits the establishment of native perennial species through competition for moisture. Cheatgrass currently occupies many burned and disturbed western rangeland sites and provides an early maturing, fine textured fuel that increases the chance of ignition as well as the rate, spread, and frequency of wildfire (Whisenant 1990).

Forage kochia (Kochia prostrata) has been planted in greenstrips (e.g. vegetative fire breaks) in an attempt to combat frequent rangeland wildfires in areas invaded by cheatgrass. Forage kochia is native to the arid and semiarid regions of Central Eurasia and is widely adapted to the Intermountain West and Great Basin regions. It is being used extensively on arid to semiarid rangelands that have sandy to clayey textured soils, are moderately to strongly alkaline and receive 6 to 14 inches of annual precipitation. 'Immigrant' forage kochia was released in 1984 and is currently the only commercially available cultivar in the United States.

Information on the fire suppression characteristics of forage kochia exists in symposium proceedings and inhouse reports, but there are no published research findings in peer-reviewed scientific journals. Thus, we have reviewed available research findings and conducted telephone interviews to assess the ability of forage kochia to suppress wildfires. Our purpose is to summarize forage kochia's greenstripping utility and to suggest future research needs. This information will benefit land managers who continually deal with rangeland wildfires.

\section{Historically Greenstripping Shows Promise}

In 1946, Platt and Jackman proposed planting fire resistant species into strips to disrupt the fire cycle and restore native plant communities on cheatgrass infested rangelands. These fuel breaks have successfully contained wildfire in chaparral communities of Southern California.

In 1985, the Bureau of Land Management (BLM) implemented a wildfire pre-suppression program called "greenstripping" (Pellant 1994). In this program, 30 to 400 feet wide strips of selected plant materials known to reduce and/or suppress the spread of wildfires were established on landscapes prone to repeated burning. By 1992, the BLM had installed 451 miles of greenstripping and it is estimated that another 200 miles have been established since. For example the Utah BLM Fillmore Office has planted 34 miles since 1994. Most of the initial greenstrips averaged 300 feet in width and were seeded along highways or railroads to reduce humancaused fires.

According to Pellent (1994) greenstrip effectiveness depends upon:

(1) disrupting fuel continuity;

(2) reducing fuel accumulation; and

(3) maintaining plants with high moisture content.

Thus, fine fuel loads within greenstrips are modified by replacing flammable vegetation that readily ignites and carries a fire with perennial, less flammable vegetation. 
Table 1. Species frequently used in greenstrips.

\begin{tabular}{|c|c|}
\hline Common name & Scientific name \\
\hline crested wheatgrass & $\begin{array}{l}\text { Agropyron cristatum J. Gaertner, and } \\
\text { A. desertorum (Fischer ex Link) Schultes }\end{array}$ \\
\hline Siberian wheatgrass & A. fragile (Roth) Candargy \\
\hline forage kochia & Kochia prostrata (L.) Schrad. \\
\hline western yarrow & $\begin{array}{l}\text { Achillea millefolium L. ssp lanulosa } \\
\text { (Nutt.) Piper }\end{array}$ \\
\hline sandberg bluegrasss & Poa secunda L. Presl \\
\hline small burnet & Sanguisorba minor Scop. \\
\hline Alfalfa & Medicago sativa $\mathrm{L}$. \\
\hline bioc flas & Limum perenne $\mathrm{L}$. \\
\hline bottlebrush squirreltail & Elymus elymoides (Raf.) Swezey \\
\hline bluebunch wheatgrass & Pseudoroegneria spicata (Purch) A. Love \\
\hline Asian beardless wildrye & Leymus multicaulis (Kar. \& Kir.) Tzvelev \\
\hline
\end{tabular}

\section{Forage Kochia Suited For Greenstripping}

Monsen (1994) described the following characteristics as important when selecting species for greenstripping on semiarid rangelands: 1) adaptability to the range sites, 2) competitiveness with annual weeds, 3) ease of establishment, 4) low flammability, 5) open canopy and spacing, 6) palatability by livestock and wildlife (for efficient removal and control of litter and fine fuel buildup), and 7) resilience and regrowth capabilities. Species most frequently used in greenstripping programs are shown in Table 1.

While many species have characteristics that meet some of the desired criteria, forage kochia demonstrates most if not all the desired greenstripping qualities.

Scientists and range managers consider 'Immigrant' forage kochia a prime candidate for use on western rangelands for fire prevention and range rehabilitation. However, there

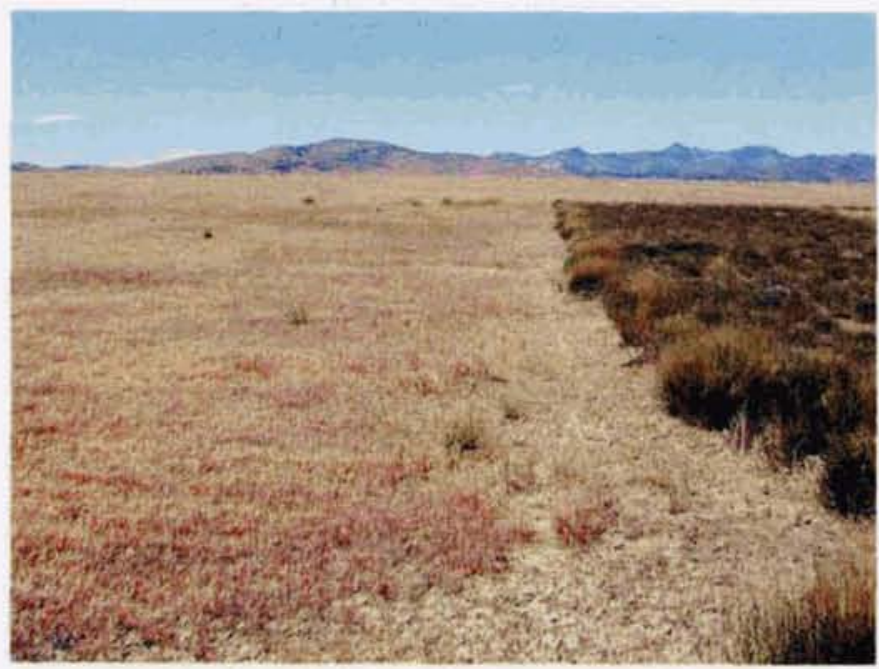

Ten-year old Immigrant forage kochia greenstrip bordering cheatgrass at Whiterock research plots near Skull Valley, Utah. is need to evaluate additional germplasm of forage kochia for its compatibility for greenstripping and other rangeland uses. Consequently, a forage kochia breeding program was initiated in 1998 at the USDA-ARS, Forage and Range Research Lab in Logan, Utah to meet the needs of Western rangelands and greenstriping programs.

Some are concerned that forage kochia will invade and suppress or eliminate native plant communities. Harrison et al. (2000) found that 'Immigrant' forage kochia may spread into disturbed and bare areas stabilizing the soil; however, there is little evidence that it is an aggressive spreader or that it will negatively impact established perennial plant communities.

In Idaho, it has been reported to encroach into alkali slick spot soils where some sensitive species may exist (Harrison et al. 2000). However, because greenstrips are frequently established in cheatgrass dominated areas to suppress large rangeland fires, the benefits of fuel reduction out weigh potential negative impacts caused by minimal spread of forage kochia. Clements et al. (1997) and Gray (personal communication, Wildlife Biologist) found that cheatgrass declined and native species numbers increased in 'Immigrant' forage kochia seedings in Nevada.

Thus, the concept has been developed that placing greenstrips at strategic locations breaks up the cheatgrass fire cycle and facilitates the return of native species to cheatgrass dominated sites.

\section{Does Forage Kochia Stop Fires?}

Pellant observed that two of the most important determinants of successful greenstrips are disrupting fuel continuity and increasing plant moisture content during the fire season. As a half shrub, forage kochia competes with and replaces cheatgrass, and maintains a high mois-

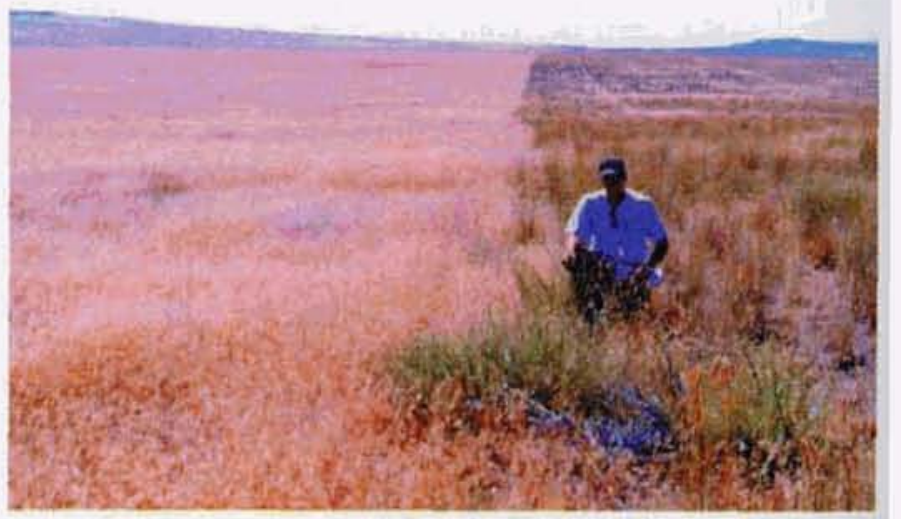

Border of twelve-year old Immigrant forage kochia and crested wheatgrass greenstrip planting near Mountain Home, Idaho. 


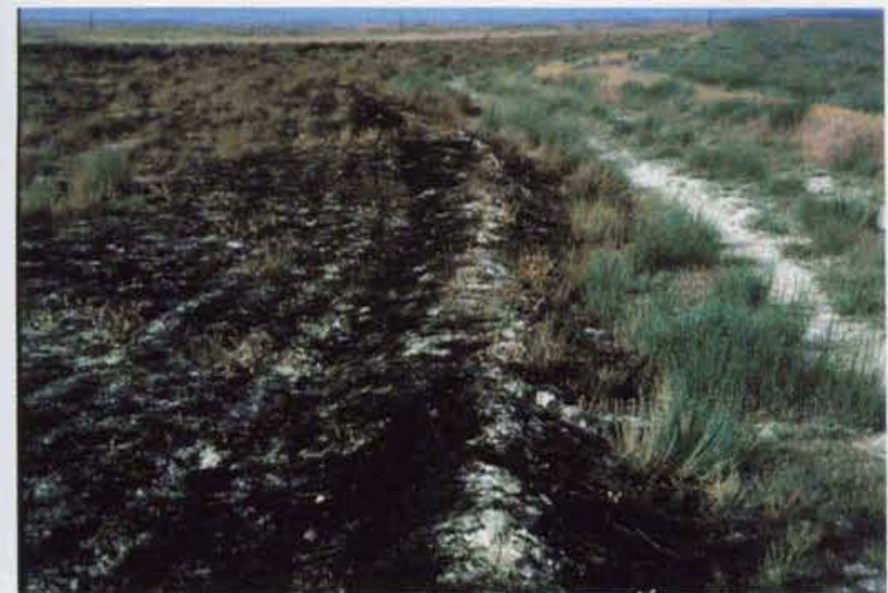

Immigrant forage kochia greenstrip stopped this wildfire in Idaho (Photo courtesy of Mike Pellant).

ture content throughout the main fire season. Pellant (1994) reported that in August, forage kochia had 4 times and 10 times the moisture content of crested wheatgrass and cheatgrass, respectively. In addition, early season water-use by forage kochia has been considered important in its competition with cheatgrass (Romo and Haferkamp 1988).

Under some conditions, forage kochia will burn when it is present with ignitable fuels, but plants are known to recover quickly. McArthur et al. (1990) were the first to report the recovery of forage kochia following fire events. Monsen and Kitchen (1999) evaluated the burning tolerance of 12 forage kochia accessions, from 1988 to 1995 , and confirmed that 'Immigrant' and several other germplasms of forage kochia quickly recovered from fire.

Forage kochia plantings primarily reduce rangeland fire intensity by reducing the flame length and making it easier to extinguish the fire (Monsen and Memmott 1999). Von Swain of the Utah BLM found that during two, 2001 fires the rate of spread and intensity were reduced on sites that contained forage kochia which allowed crews to put out the fires.

In addition, BLM Fire Management Specialist Dan Washington found that when a 1998 central Utah wildfire reached a forage kochia seeding, flame lengths were reduced from approximately 10 feet to less than one foot. Similarly, Allen Rasmussen of Utah State University has noted that the flame length of wildfires drops upon contact with forage kochia plantings because of a breakup of fine fuel continuity.

Reports not only indicate that forage kochia reduces flame length and intensity, but can also suppress or even stop wildfires. Idaho BLM rangeland ecologist Mike Pellant concluded that forage kochia was superior to

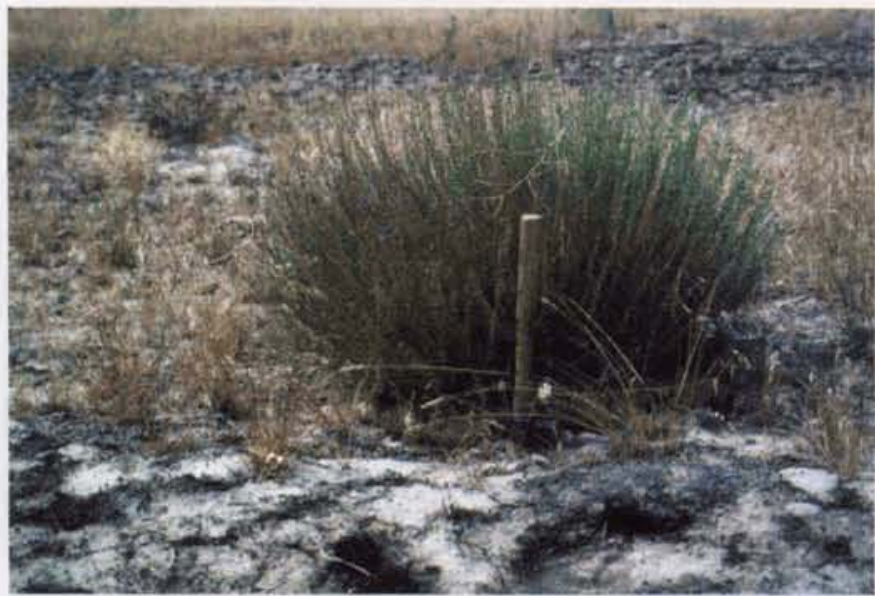

Unburned Immigrant forage kochia plant after wildfire (Photo courtesy of Mike Pellant).

other commonly used species in stopping wildfires on livestock grazed rangelands. He observed that a wildfire near Mountain Home, Idaho burned to a forage kochia greenstrip and stopped because of the green biomass and sparsity of contiguous fine fuels.

Utah BLM Fuel Specialist Dan Symmes reported that during a controlled burn in June 2001, "the fire went out when it hit a forage kochia planting," with wind speeds up to $5 \mathrm{mph}$. In another example, C.D. Clements, USDA-ARS Range Scientist, noted that a wildfire between Battle Mountain and Elko, Nevada stopped immediately when it came to a seeding of forage kochia.

Only a few burning trials of forage kochia have been conducted. Robert Newhall (Utah State Extension Service Conservation Agronomist), Richard Page (BLM, former Watershed Program Leader), and local BLM officials conducted a controlled burn on a three year old stand of forage kochia at the White Rock forage kochia cooperative research plots in Skull Valley, Utah in late July 1993.

When cheatgrass was ignited using a butane burner they found that the 50 foot wide forage kochia plantings did not burn (unpublished data). In 1995, a wildfire went through the same research plots burning the cheatgrass between the 50 foot test strips, but only about $29 \%$ of the forage kochia.

Monsen (1994) conducted greenstrip burning trials at Nephi, Utah and found that 'Immigrant' forage kochia demonstrated excellent utility as a greenstrip species. Monsen and Memmott (1999) found that fire burned only two feet into forage kochia test strips before it went out, even though wind speed was $16.3 \mathrm{mph}$. They also reported that only when winds exceeded $20-25 \mathrm{mph}$, and plots contained litter, did the fire burn slowly and erratically through the forage kochia plots. 


\section{More Research Needed}

Collectively, these observations and reports suggest that forage kochia is a very effective greenstrip species for fire-prone landscapes in the Great Basin and Western United States. Forage kochia provides resource managers with an opportunity to decrease fire frequency by successfully competing with and decreasing cheatgrass density. Additional quantitative research is necessary before the full utility of forage kochia greenstrips is known.

Research on forage kochia should identify: (1) its range of adaptation, (2) the most efficient greenstrip width and best establishment procedures, and (3) its ecological compatibility with other desirable greenstrip species. Although several scientists are currently conducting research on forage kochia, there still remains the lack of published data on its fire suppressant qualities. We hope future research will foster appropriate recommendations and identify limitations regarding the use of forage kochia in greenstrips as a widespread management option to reduce fire fuels and extensive wildfires.

About the authors: Harrison is range scientist, Utah State University, Logan, Utah 84322 (emeritus USDA-NRCS state resource conservationist); Waldron is research geneticist, USDA, Agricultural Research Service, Forage and Range Research Lab, Logan, Utah 84322-6300; Jensen is research geneticist, USDA, Agricultural Research Service, Forage and Range Research Lab, Logan, Utah 84322-6300; Page is emeritus range scientist, USDI, Bureau of Land Management; Monaco is research ecologist, USDA, Agricultural Research Service, Forage and Range Research Lab, Logan, Utah 84322-6300; Horton is rangeland scientist, USDA, Agricultural Research Service, Forage and Range Research Lab, Logan, Utah 84322-6300; and Palazzo is agronomist, United States Army Cold Regions Research and Engineering Laboratory, Hanover, New Hampshire 03755-1290.

The authors gratefully thank the numerous researchers and land managers cited in this article for their willing contributions, unpublished research information, and pictures. We also acknowledge Strategic Environmental Research and Development Program (SERDP) Project CSI103 funding which allowed the accumulation of this information.

\section{References}

Clements, C. D., K. J. Gray, and J. A. Young. 1997. Forage kochia: to seed or not to seed. Rangelands 19(4): 29-31.

Harrison, R.D., N.J. Chatterton, B.L. Waldron, B.W. Davenport, A.J. Palazzo, W.H. Horton, and K.H. Asay. 2000. Forage Kochia - Its compatibility and potential aggressiveness on Intermountain rangelands. Utah Agr. Exp. Sta. Res. Rpt. 162. Utah State Univ., Logan, UT 84322-4820. pp. 66. (Available on-line at http://www.agx.usu.edu/agx/ResearchReports/KOCHIA/kochia.ht mi).

McArthur, E.D., A.C. Blauer, and R. Stevens. 1990. Forage kochia competition with cheatgrass in central Utah. p. 56-65. In E.D. McArthur, E.M. Romney, S.D. Smith, and P.T. Tueller (comps.). Proceedings-Symposium on cheatgrass invasion, shrub die-off, and other aspects of shrub biology and management. 5-7 April 1989. Las Vegas, NV. GEN. Tech. Rep. INT-276. USDA Forest Service, Intermountain Research Station, Ogden, UT. 351 p.

Monsen, S. B. 1994. Selection of plants for fire suppression on semiarid sites. p. 363-373. In: S.B. Monsen and S.G. Kitchen (comps.). Proceedings-symposium on ecology and management of annual rangelands. 18-21 May 1992. Boise, ID. Gen. Tech. Rep. INTGTR-313. USDA Forest Service, Intermountain Research Station, Ogden, UT. $416 \mathrm{p}$.

Monsen, S.B. and S.G. Kitchen. 1999. Variation in burning tolerance among forage kochia accessions. p. 92-100. In: Cooperative research studies 1989-1998. USDA Forest Service, Rocky Mountain Research Station, Shrub Sciences Lab., Provo, UT. Report submitted to U.S. Dept. of Interior, Intermountain Greenstripping Program. Boise, ID. 285 p.

Monsen, S.B. and K.L. Memmott. 1999. Comparison of burning reliance of forage kochia, crested wheatgrass, bluebunch wheatgrass, small burnet, and western yarrow in simulated burned greenstrips. p. 113-122. In: Cooperative research studies 1989-1998. USDA Forest Service, Rocky Mountain Research Station, Shrub Sciences Lab., Provo, UT. Report submitted to U.S. Dept. of Interior, Intermountain Greenstripping Program. Boise, ID. 285 p.

Pellant, M. 1990. The cheatgrass-wildfire cycle: Are there any solutions? p. 11-18. In E.D. McArthur, E.M. Romney, S.D. Smith, and P.T. Tueller (comps.). Proceedings-Symposium on cheatgrass invasion, shrub die-off, and other aspects of shrub biology and management. 5-7 April 1989. Las Vegas, NV. GEN. Tech. Rep. INT276. USDA Forest Service, Intermountain Research Station, Ogden, UT. $351 \mathrm{p}$.

Pellant, M. 1994. History and applications of the intermountain greenstripping program. p. 63-68. In: S.B. Monsen and S.G. Kitchen (comps.). Proceedings-symposium on ecology and management of annual rangelands. 18-21 May 1992. Boise, ID. Gen. Tech. Rep. INT-GTR-313. USDA Forest Service, Intermountain Research Station, Ogden, UT. 416 p.

Romo, J. T. and M. R. Haferkamp. 1988. Comparative water relations in Artemisia tridentata Nutt. subsp wyomingensis and Kochia prostrata (L.) Schrad. J. Arid. Eviron. 15:53-64.

Whisenant, S. G. 1990. Changing fire frequencies on Idaho's Snake River Plains: ecological and management implications. p. 4-10. In E.D. McArthur, E.M. Romney, S.D. Smith, and P.T. Tueller (comps.). Proceedings-Symposium on cheatgrass invasion, shrub die-off, and other aspects of shrub biology and management. 5-7 April 1989. Las Vegas, NV. GEN. Tech. Rep. INT-276. USDA Forest Service, Intermountain Research Station, Ogden, UT. 351 p.

\section{Additional Reading}

Green, L. R. 1977. Fuelbreaks and other fuel modifications for wildland fire control. Agr. Handb. 499. USDA, FS. U.S. Gov. Printing office. Washington, D.C.

Hunter, R. 1990. Recent increases in Bromus populations of the Nevada test site. In E.D. McArthur, E.M. Romney, S.D. Smith, and P.T. Tueller (comps.). Proceedings-Symposium on cheatgrass invasion, shrub die-off, and other aspects of shrub biology and management. 5-7 April 1989. Las Vegas, NV. GEN. Tech. Rep. INT276. USDA Forest Service, Intermountain Research Station, Ogden, UT. $351 \mathrm{p}$.

Keller, W. and A. T. Bleak. 1974. Kochia prostrata: a shrub for western range? Utah Sci. 34:24-25.

Larin, I. V. 1956. Pasture economy and meadow cultivation p. 168170. (translated to English 1962 and published by Israel Program for Scientific Translations, Jerusalem). 
Melgoza, A.G., R.S. Nowak, and R.J. Tousch. 1990. Soil water exploitation after fire: Competition between Bromus tectorum (cheatgrass) and two native species. Oecologia 83:7-13.

Peters, E.F. and S.C. Bunting. 1994. Fire conditions pre- and postoccurrence of annual grasses on the Snake River Plain. p. 31-36. In S.B. Monsen and S.G. Kitchen (comps.). Proceedings-symposium on ecology and management of annual rangelands. 18-21 May 1992. Boise, ID. Gen. Tech. Rep. INT-GTR-313. USDA Forest Service, Intermountain Research Station, Ogden, UT. 416 p. Platt, K. and E. R. Jackman. 1946. The cheatgrass problem in Oregon. Bull. 668. Oregon Agricultural Experiment Station. Corvallis, OR. 48 p.

Plummer, A. P. 1977. Revegetation of disturbed Intermountain area sites. p. 302-339. In J.L. Thames, ed. Reclamation and use of disturbed lands in the Southwest. Tucson, AZ. University of Arizona Press.

Robertson, J.H. and C.K. Pearce. 1945. Artificial reseeding and closed communities. Northwest Sci. 19:58-66.
Stevens, R. and K. R. Jorgensen, E. D. McArthur, and J.N. Davis. 1985. 'Immigrant' forage kochia. Rangelands 7:22-23.

Stewart, G. and A. C. Hull. 1949. Cheatgrass (Bromus tectorum) an ecologic intruder in southern Idaho. Ecology. 30:58-74.

Waldron, B.L., R.D. Harrison, N.I. Dzyubenko, A. Khusainov, S. Shuvalov, and S. Alexanian. 2001. Kochia prostrata germplasm collection expedition to Kazakhstan. p.113-117. In D.E. McArthur and D.J. Fairbanks (comps.) Proc Shrubland Ecosystem Genetics and Biodiversity Symp., Provo, UT. 13-15 June 2000. Proceedings RMRS-P-21. USDA, Forest Service, Rocky Mountain Res. Station. Ogden, UT.

Young, J.A. and R.A. Evans. 1978. Population dynamics after wildfires in sagebrush grasslands, J. Range Manage. 31:283-289.

Young, J., R. E. Eckert, and R. J. Evan. 1979. Historical perspectives regarding the sagebrush ecosystem. p. 1-12. In The sagebrush ecosystem: a symposium. April 1978. Utah State Univ. Logan, UT. 